2. Object-oriented - is object, but has method shortcomings: are convenient for object interaction description of one class, but for object interactions of different classes, that is more often used in a $\mathrm{DB}$, it is inconvenient as it is compelled to use the asymmetrical device of "friendly" functions.

\title{
Effective Interaction with the DIM DBMS
}

\author{
D.V.Antonov <dmitrii.antonov@gmail.com>, \\ V.S.Roublev<roublev@mail.ru> \\ Demidov Yaroslavl State University, ul. Sovetskaya,10, \\ Yaroslavl 150000, Russia
}

Abstract. In the article the review of tools used in a new type object DBMS for increasing the efficiency of access to data is provided. Some object DIM DBMS features based on the use of the classes of object relations as object sets (inheritance, inclusion, interaction and history) and object relations (inheritance, internal inheritance, inclusion, internal inclusion, interaction and history) are described. The description of the subject domain is entered by means of an object and dynamic data model (OD-model), and DIM DBMS completeness for any OD-model is justified. An ODQL object query language allowing to combine the exact description complexity with the simplicity of use due to two

query level introduction is described. For the elucidation of the most effective way of the appeal to DIM DBMS the study of various query technologies for this environment is conducted, and mechanisms for user work with it are developed and realized. Software development "The Generator of ODQL-queries" is considered which is necessary for simplification of query creation to DIM DBMS, needless for the user to know the syntax of a modern query language. Problems of converting data from the existing DBMS into DIM DBMS are considered.

Keywords: dim; dbms; od-model; odql; transformation algorithm; converter

DOI: $10.15514 /$ ISPRAS-2015-27(3)-24

For citation: Antonov D.V., Roublev V.S. Effective Interaction with the DIM DBMS Trudy ISP RAN/Proc. ISP RAS, vol. 27, issue 3, 2015, pp. 343-350. DOI: 10.15514/ISPRAS2015-27(3)-24.

\section{Introduction}

The architectures of modern DBMS are various, but all of them have as the basis one of extended models: relational (Codd, 1970), object-oriented (etc., 1995), object-relational (Darwin, etc., 1996), temporal (Kostenko, etc., 2007)

The available DBMS technologies possess some shortcomings:

1. a relational - one is universal, effective in the realization but rather complex for use, as it is necessary to project in terms of a large number of tables, and not objects. technologies, but it has shortcomings of both technologies.

4. Temporal - has advantages in opportunities of data change preservation history, but not their types.

Shortcomings of the available DBMS models allowed to think of the DBMS new technology creation which uses advantages of the available technologies of the listed above systems. In [1] a new object approach to DBMS creation is described which assumes not only a change of these objects, but also types of objects change possibility, i.e. the database schemes called a dynamic information model (DIM).

DIM DBMS has some advantages in comparison with other systems:

1. it is object, and the object relation device (including internal inheritance and internal inclusion) allows to describe adequately OD-models data, and the interactions device allows to describe symmetrically laws of data change and data types;

2. unlike the temporal one it allows to keep data change history, and their types.

Now in many areas of human activity for the description of various processes the discrete determined models are often used.

Model discretization in this case is understood as a final, though potentially unlimited number of model objects, and determinancy of model is understood as the determined laws of the model objects behavior.

Formalization of the discrete determined model has led to creation of the object and dynamic model (OD-model), and for the adequate description of its data formalization of the class scheme DIM and formalization of the OD-model static description by the class scheme DIM [2] are entered into DIM.

We will call a group of elements

$\left(\mathrm{O}, \mathrm{A}, \overline{\mathrm{A}}(\mathrm{o}), \mathrm{V}(\mathrm{o}), \mathrm{L}_{\mathrm{p}}, \mathrm{L}_{\mathrm{o}}, \mathrm{L}_{\mathrm{f}}, \overline{\mathrm{A}}_{\mathrm{L}_{\mathrm{f}}}\left(\mathrm{o}_{\mathrm{l}}^{\mathrm{j}}\right), \mathrm{V}_{\mathrm{L}_{\mathrm{f}}}\left(\mathrm{o}_{\mathrm{l}}^{\mathrm{f}}\right), \mathrm{F}, \mathrm{T}\right)$,

an OD-model where

$\mathrm{O}-\mathrm{a}$ final objects set,

$\mathrm{A}=\mathrm{U}_{\mathrm{O}} A_{O}-\mathrm{a}$ final set of object properties with types of these properties (this set element of the pair $\left(\mathrm{a}, \mathrm{V}^{\mathrm{a}}\right)$ - property, property type),

$\overline{\mathrm{A}}(\mathrm{o})$ - a cortege function of object properties o,

$\mathrm{V}(\mathrm{o})$ - a cortege function of object properties values (orderliness of object properties values of o corresponds to orderliness of this object properties in a cortege $\overline{\mathrm{A}}(\mathrm{o})$ ), 
$\mathrm{L}_{\mathrm{p}}=\mathrm{U}_{\mathrm{j} \in \mathrm{L}_{\mathrm{p}}}\left\{\mathrm{l}_{\mathrm{j}}^{\mathrm{p}}=\{\mathrm{o}, 01\}\right\}$ - a set of object simple communications,

$\mathrm{L}_{\mathrm{o}}$ - an objects-communications set $\left(\mathrm{O} \cap \mathrm{L}_{\mathrm{o}}=\emptyset\right)$,

$\mathrm{L}_{\mathrm{f}}=\mathrm{U}_{\mathrm{j} \in \mathrm{L}_{\mathrm{f}}}\left\{\left(\mathrm{l}_{\mathrm{j}}^{\mathrm{f}}, \mathrm{o}_{\mathrm{l}}^{\mathrm{j}} \in \mathrm{L}_{\mathrm{o}}\right)\right\}$ - a set of objects functional communications,

$\overline{\mathrm{A}}_{\mathrm{L}_{\mathrm{f}}}\left(\mathrm{o}_{\mathrm{l}}^{\mathrm{j}}\right)$ - a cortege function of object-communication attributes $\mathrm{o}_{\mathrm{l}}^{\mathrm{j}}$ functional communications $\mathrm{L}_{\mathrm{f}}$

$\mathrm{V}_{\mathrm{L}_{\mathrm{f}}}\left(\mathrm{o}_{\mathrm{l}}^{\mathrm{f}}\right)$ - a cortege function of object-communication attributes values $\mathrm{o}_{\mathrm{l}}^{\mathrm{f}}$ functional communications $\mathrm{L}_{\mathrm{f}}$

$\mathrm{F}$ - a final set of algorithmic procedures of object property values change and object change,

$\mathrm{T}$ - a discrete time scale.

\section{ODQL object queries language}

The object concept is complicated, as for the allocation of its properties and their values it is required to work both with object class properties, and with the properties received in inheritance. Therefore, an actual task is to introduce such language, by using which a user could set objects of one class (or several classes with their communications), considering not only parameters and the properties of a class inclusion but also all the inherited properties.

The SQL query language for RSUBD is evident, but is not objective. The ODMG group, being the founder of one of the OOBD technologies, developed the standard of the object OQL query language (see [3]). But, first, this technology does not pursue the aim of adaptive DB creation which will be able to change dynamically the data scheme, and secondly, the classes relations entered in it do not allow to describe adequately any discrete determined models, that is also the property of the DIM technology proved in the same place. Therefore, the object query language allowing to carry out manipulations with data to DIM is necessary. This language by means of the constructions must define precisely what we wish to allocate, and it must be simple enough in use to allow one to set visually the information which needs to be allocated with a small amount of clear constructions.

The complete description of the ODQL language can be found in [3]

\section{Problem definition}

The DB transformation from the existing DBMS to DIM puts a problem of data converting.

As there are DBMS of different types, no uniform algorithm for data converting from any DBMS to DIM can be written, but it is possible to use the OD-model, that is, at first to transform the available DB to the OD-model, and then to use the available OD-model transformation algorithm to the structure of DIM DBMS, following the theorem of the static completeness described in [2]

The theorem of static completeness.
Any OD-model OD for any moment \$t lin TS in it can be statically described by means of a scheme $\mathrm{S}$ of the DIM classes which is in a normal form.

For transfer of the existing DB on DIM DBMS the program which can transform data from relational DBMS was created. Other types, such as: temporal, objectoriented and object and relational, at the moment are at a testing stage. Such transformation requires two stages. At the first stage the DB is converted into the OD model. Then the model is converted into DIM DBMS.

\section{Algorithm of receiving display for any model and its realization}

For a start, it is necessary to receive a display for any model. The algorithm of receiving the display appears as follows:

1. A series of queries for obtaining a list of the tables, the fields corresponding to them, communications among tables presented in DB, and also sets of the values which are available there, is carried out.

2. The arrays which are responsible for the sets corresponding to sets of ODmodel are filled.

\section{Transformation algorithm of a relational DB to DIM DB}

The algorithm of receiving the display for a relational model looks in many respects similar to the general algorithm, but has some differences, namely, such an operation procedure

1. the query for obtaining the table list and the fields corresponding to them presented in a DB is performed;

2. on the basis of the obtained data, the array which is responsible for a table name set of a transferable DB is filled up;

3. the two-dimensional array is filled up (as it is necessary to compare the name of each field with the type corresponding to it) which is responsible for a field set of all tables (information about the name of fields and their type is registered in the array);

4. a series of queries to tables for obtaining information about the data written down in their fields is performed(the data sets corresponding to each field are read out);

5. the array which is responsible for a set of the values which are written down in the table is filled (each set is divided by a special tag to further distinguish sets from each other);

6. a series of queries is performed to find out the existence of externa indexes, therefore, of communications between tables;

7. the array which is responsible for a set of communications among tables is filled. 
As a result of the algorithm execution we receive a set of arrays containing information on a set of properties, objects and communications. On the basis of these data the model is formed which corresponds to the description of OD-model from which by means of a special program it is possible to receive a structure corresponding to the DIM DBMS metalevel.

\section{Converter}

The existing DB in DIM DBMS transfer requires creating the program which will be able to transform data from different types of DBMS, such as: relational, temporal, object-oriented and object-relational. Such transformation requires two stages. At the first one the DB is converted into the OD model, then the model is converted into DIM.

It was developed the program "DIM DBMS Converter" whose first stage of work is data transformation from a relational DB to the OD model.

The principle of converting in the OD model consists in data transfer from any DBMS in the general structure from which there is a transformation to DIM DBMS For compliance to structure of the OD model the converter possesses an arrays set which emulate this model. Thus, when reading from DBMS all data are filtered at the program level and make the OD model (see section I) though they are not connected among themselves yet. Further, the algorithm is used in which these tables contact the relevant fields groups (as a rule, each group begins with the field "Id"). Next, the program analyzes fields names regarding partial coincidence, and, on this basis, it forms communications between the tables corresponding to this field. As in the existing DB there can be features of communications among tables, the user can preview and correct OD model elements.

\section{7. $O D Q L$ query generator}

As a drafting object query demands from the user the knowledge of objects classes and their communications that not always he knows precisely, the creation of an intellectual system which will ease queries creation in object DIM DBMS is necessary. We will call this system "ODQL query generator".

The generator represents a set of components that help the user to visually orient in the structure of a DB and to make a query, using the interactive interface. For ensuring interactivity the system allowing to choose from the presented DB elements necessary for the user is used. At the initial stage the user chooses the necessary parameters, then specifies a class if such parameters meet at severa classes. If necessary he specifies conditions for this choice. Also the user can specify at this stage, whether performance of the conditions connected with other classes or parameters of the chosen class is necessary. If necessary, the user is offered to choose with what classes or parameters he wants to connect query conditions, and the list of classes contains only those that are connected with the class chosen at the moment. Thus, in the system it is realized the possibility of the correctness of required data, therefore the problem is solved with the creation of complex queries.

The development of an intellectual system which allows to make queries for DIM DBMS in a form comfortable for the user was the result of the work.

\section{Conclusion}

As a result, the developed algorithms are used in the created "DIM DBMS Converter" program for transformation of relational DB to DIM DBMS DB. The converter was tested on Oracle DB and at the moment the program passes the state of registration. Also it was performed the comparative analysis of query technologies [4] and it is developed a software "ODQL query generator" [5], which allows to generate complex queries to the user who does not know all complex objects structure, but objects properties which need to be allocated. Thus, the objectives on creating effective remedies of the access to data DIM are reached.

\section{References}

[1]. Pisarenko D.S., Rublev V.S. Ob"ektnaya SUBD Dinamicheskaya informatsionnaya model' i ee osnovnye kontseptsii // Modelirovanie i analiz informatsionnykh sistem. 2009. - vol.16, no.1. - pp.62-91 (in Russian).

2]. Rublev V.S. Teorema o staticheskoi polnote SUBD DIM // Problemyteoretichesko kibernetiki. Materialy XVII mezhdunarodnoi konferentsii (Kazan', 16 - 20 iyunya 2014g.). Kazan': Otechestvo. — 2014. — pp.242-245 (in Russian).

[3]. Yazyk ob"ektnykh zaprosov dinamicheskoi informatsionnoi modeli DIM// Modelirovanie i analiz informatsionnykh sistem. vol. 17, no.3, 2010. pp.144-161.

4]. Antonov D.V., Rublev V.S. Analiz tekhnologii vychisleniya ODQL-zaprosov SUBD DIM // Yaroslavskii pedagogicheskii vestnik. — 2013. — vol.3, no.4. — pp.93-97 (in Russian).

[5]. Antonov D. V. Zaprosy SUBD DIM i ikh generatsiya // Shest'desyat sed'maya regional'naya nauchno-tekhnicheskaya konferentsiya studentov, magistrantov aspirantov vysshikh uchebnykh zavedenii s mezhdunarodnym uchastiem / red. Doronin V B. - Yaroslavl': Izdatel'stvo YaGTU, 2014. - vol. 2. - pp. 284. - ISBN 978-5-99140365-8 (ch. 2) ISBN 978-5-9914-0363-4 (in Russian). 


\section{Эфффективное взаимодействие с СУБД DIM}

Д.В.Антонов $<$ dmitrii.antonov@gmail.com>, В.С.Рублев <roublev@mail.ru>

ЯрГУ им.П.Г.Демидова, ул.Советская, 10, Ярославль 150000, Россия

Аннотация. В статье приводится обзор средств, используемых в объектной СУБД нового типа для повышения эффективности доступа к данным. Описываются особенности объектной СУБД DIM, основанные на использовании отношений классов объектов (как множеств объектов): наследования, включения, взаимодействия и истории и отношений объектов: наследования, внутреннего наследования, включения, внутреннего включения, взаимодействия и истории. Вводится описание предметной области при помощи объектно-динамической модели данных (OD-модели) и обосновывается полнота СУБД DIM для произвольной OD-модели. Описывается объектный язык запросов ODQL, позволяющий совместить сложность точного описания с простотой использования за счет введения двух уровней запросов. В целях выяснения наиболее эффективного способа обращения к СУБД DIM проводится исследование различных запросных технологий для этой среды, а также разрабатываются и реализуются механизмы для работы пользователей с ней. Для этого разрабатывается комплекс программных средств, необходимых для работы с СУБД DIM. Рассматривается разработка ПО «Генератор ODQL-запросов», который нужен для упрощения построения запросов к СУБД DIM без необходимости для пользователя в обязательном порядке знать синтаксис нового языка запросов. Рассматриваются пути решения проблемы конвертации данных из существующих СУБД в СУБД DIM.

Keywords: dim; субд; od-модель; odql; алгоритм преобразования; конвертер

DOI: $10.15514 /$ ISPRAS-2015-27(3)-24

Для цитирования: Антонов Д.В., Рублев В.С. Эффективное взаимодействие с СУБД DIM. Труды ИСП РAH, том 27, вып. 3, 2015 г., стр. 343-350 (на английском языке). DOI: $10.15514 /$ ISPRAS-2015-27(3)-24

\section{Список литературы}

[1]. Писаренко Д.С., Рублев В.С. Объектная СУБД Динамическая информационная модель и ее основные концепции // Моделирование и анализ информационных систем. - 2009. - Т.16, №1, С. 62-91.

[2]. Рублев В.С. Теорема о статической полноте СУБД DIM// Проблемы теоретической кибернетики. Материалы XVII международной конференции (Казань, 16 - 20 июня 2014г.). Казань: Отечество - 2014. - С. 242-245.

[3]. Рублев В.С. Язык объектных запросов динамической информационной модели DIM // Моделирование и анализ информационных систем. Т.17, №3, 2010. - С. 144-161.

[4]. Антонов Д.В., Рублев В.С. «Анализ технологий вычисления ODQL-запросов

СУБД DIM» // Ярославский педагогический вестник. 2013. Т. 3. № 4. С. 93-97. региональная научно-техническая конференция студентов, магистрантов и аспирантов высших учебных заведений с международным участием/ ред. Доронина В Б. - Ярославль : Издательство ЯГТУ, 2014. - Т. 2. - стр. 284 